\title{
Food, Technology and Culture in the Late Bronze Age of Southern Britain: Perforated Clay Plates of the Lower Thames Valley
}

\author{
By TIMOTHY CHAMPION ${ }^{1}$
}

Perforated plates of fired clay have long been recognised as a component of Late Bronze Age material culture in south-eastern England, but recent developer-funded excavations have produced a wealth of new evidence. These artefacts, showing a considerable degree of standardisation, are now known from more than 70 sites, which show a markedly riverine and estuarine distribution along the lower Thames. Their function is still uncertain, but it is suggested that they were parts of ovens for baking bread, a new technology for food preparation in the later Bronze Age. Some of the largest assemblages of such plates are found at strongly defended sites, and it is further suggested that the baking and consumption of bread was particularly associated with such sites of social authority. The estuarine distribution is discussed in this paper, and it presents further evidence for the regionally distinctive nature of food consumption in later prehistory.

Keywords: perforated clay plates, Late Bronze Age, food preparation, lower Thames valley, wheat varieties, bread

At a meeting of the Royal Archaeological Institute in London on 7 February 1867 an object was exhibited for discussion. It was a fragment of perforated clay 'plaque', discovered the previous year during gravel-digging at Coombe Warren, Kingston Hill, Surrey. It attracted considerable attention, but its function 'appeared very doubtful; and no satisfactory suggestion was offered at the meeting' (Tregellas 1868, 155). During the following century occasional finds of similar objects were made in south-eastern England. They were eventually recognised as an artefact specific to the Late Bronze Age of the middle and lower Thames valley (Champion 1980, 237-8 \& figs 8-9); though various suggestions had been made, none was persuasive and their function still appeared 'very doubtful'. Since then there has been a rapid increase in the rate of discovery, as a result of the amount of excavation in advance of development in the area. Finds are now known from more than 70 sites (Table 1) and it is possible to reassess their chronology and distribution, as well as to suggest a social context and a possible function.

\footnotetext{
${ }^{1}$ Faculty of Humanities (Archaeology), University of Southampton, Southampton, SO17 1BF, UK tcc@soton.ac.uk
}

Information for the present study has been gathered through a variety of methods over a considerable period of time. The original article (Champion 1980), followed especially by the detailed publication of some key assemblages such as the finds from Queen Mary's Hospital, Carshalton (Adkins \& Needham 1985) and Mucking North Ring (Bond 1988), drew attention to these artefacts and greatly increased the chances of their correct identification and publication. Monitoring of published excavation reports from the region therefore provided the first line of new information. Subsequent enquiries to county archaeologists and museum curators produced further information, often with reference to recent or even current excavations. Finally, enquiries to the commercial companies carrying out the excavations were answered with details of the discoveries, and often, very generously, with details about further sites as yet unknown to the author. More than half the sites now known have been excavated since 1990 . No systematic trawl of the very extensive grey literature has been undertaken, and the list of sites in Table 1 makes no claim to being exhaustive.

These items have often been referred to as 'plaques', following the original terminology of 1868 , but also 
TABLE 1: SITES WITH PERFORATED CLAY PLATES

\begin{tabular}{|c|c|c|c|c|}
\hline No. & Location & Site & Quantity & Reference \\
\hline 1 & Egham & Petters Sports Field & $3 ?+$ & O’Connell 1986, 60 \& fig. $40,6-8$ \\
\hline 2 & Egham & Thorpe Lea Nurseries & 1 & Hayman et al. 2012,130 \& fig. 5.30, no. 59 \\
\hline \multirow[t]{3}{*}{3} & \multirow{3}{*}{ Egham } & \multirow[t]{3}{*}{ Runnymede } & \multirow[t]{3}{*}{4} & Longley 1980,31 \& fig. $17,57-58$ \\
\hline & & & & Needham \& Longley 1980, 411, \& fig. 4.2 \\
\hline & & & & Needham 1991, 152 \& fig. 66 \\
\hline 4 & Heatnrow & lerminal s & 3 & Framework Archaeology 2010, 192 \& fig. 3.46 \\
\hline 5 & \multirow[b]{2}{*}{ Laleham } & Boyer’s Pit & 5 & Champion 1980, 237-8, fig. 8 \\
\hline 6 & & Home Farm & $8.7 \mathrm{~kg}$ & Lambrick 2009, 164 \& fig. 5.15b \\
\hline 7 & West Drayton & Holloway Close (M4 Widening) & ? & Cotton et al. 1986, 48; Hoad et al. 2010, 51 \\
\hline 8 & Harmondsworth & Holloway Lane & ? & Cotton et al. 1986, 48; Hoad et al. 2010, 51 \\
\hline 9 & Sipson & Home Farm, Harmondsworth Lane & ? & Hoad et al. 2010, 51 \\
\hline 10 & Harlington & Imperial College Sports Ground & ? & Cotton et al. 1986, 48 \\
\hline 11 & Dawley & Stockley Park & ? & $\begin{array}{l}\text { Grimes \& Close-Brooks 1993, 342; } \\
\text { Hoad et al. 2010, } 51\end{array}$ \\
\hline 12 & Heathrow & Caesar's Camp & 1 & Grimes \& Close-Brooks 1993, 342, 354 \& fig. 25, 17 \\
\hline 13 & Harlington & Cranford Lane & ? & Hoad et al. 2010, 51 \\
\hline 14 & East Molesey & Hurst Park & $>30$ & Laidlaw in Andrews \& Crockett 1996, 92 \& fig. 50 \\
\hline 15 & Isleworth & Busch Corner & ? & Kendall 2000, 97 \\
\hline 16 & Kingston & Coombe Warren & $6 ?+$ & Tregellas 1868; Field \& Needham 1986, 139-40 \\
\hline 17 & Raynes Park & Royal Sun Alliance Sports Field & 2 & F. Meddens pers. comm. \\
\hline 18 & Carshalton & Queen Mary’s Hospital & 20 & $\begin{array}{l}\text { Adkins \& Needham 1985, 33-8, figs 12-13; } \\
\text { Groves \& Lovell } 2002\end{array}$ \\
\hline 19 & Beddington & London Road & & Bagwell et al. 2001, 299 \\
\hline 20 & Carshalton & Westcroft Road & 3 & Proctor $2002,81,86$, fig. 10, S1-3 \\
\hline 21 & Beddington & Sewage Works & 49 & Adkins \& Adkins in Howell $2005,63-4$ \& fig. 56 \\
\hline 22 & Southwark & Brockham Street & 1 & Sidell et al. 2002, 43 \\
\hline 23 & Southwark & Harper Road & 1 & T. Clifford pers. comm. \\
\hline 24 & Southwark & 11-19 St Thomas St & 1 & Sidell et al. 2002, $43 \& 92$ \\
\hline 25 & Southwark & Fenning's Wharf, Tooley Street & 6 & Sidell et al. 2002, 43, 91 \& fig. 43 \\
\hline 26 & Stratford & Olympic Park & 13 & Leivers in Powell 2012, 244-5 \\
\hline 27 & Dagenham & Heathway & 3 & F. Meddens pers. comm. \\
\hline 28 & South Hornchurch & & 58 & Harrison in Guttman \& Last $2000,344 \&$ fig. $18,3-4$ \\
\hline 29 & Dartford & Football Club & 3 & Poole in Simmonds et al. 2011, 265 \& fig. 13.3, 1-3 \\
\hline 30 & Darenth & Gravel pit & 1 & Philp et al. 1998,60 \& fig. 20, 223 \\
\hline 31 & Darenth & A2/A282 Improvement Scheme & 4 & Poole in Simmonds et al. 2011, 137-8 \& fig. 5.12, $1-4$ \\
\hline 32 & Eynsford-Horton Kirby Pipeline & Area D & 1 ? & Poole in Simmonds et al. 2011, 232 \\
\hline 33 & A2 Pepper Hill to Cobham & Site B & 2 & Stansbie in Allen et al. 2012, 77 \& fig. 2.41, 1-2 \\
\hline 34 & Tollgate & & 4 & Bull 2006, 11 \\
\hline 35 & Cobham & Golf Course & 3 & Davies 2006, 11-15 \\
\hline 36 & Isle of Grain-Shorne Pipeline & Site $\mathrm{H}$ & $206 ?+$ & G. Dawkes pers. comm. \\
\hline 37 & Frindsbury & Quarry House & 1 & Arnold 1887, pl. 1, 4-5 \\
\hline 38 & Isle of Grain-Shorne Pipeline & Site $\mathrm{F}$ & 1 & G. Dawkes pers. comm. \\
\hline 39 & Hoo St Werburgh & & ? & Moore 2002, $263 \&$ 274, fig. 4, 3-4 \\
\hline
\end{tabular}


Table 1. Continued

\begin{tabular}{|c|c|c|c|c|}
\hline No. & Location & Site & Quantity & Reference \\
\hline 40 & Isle of Grain-Shorne Pipeline & Site B & 11 & G. Dawkes pers. comm. \\
\hline 41 & Allhallows & Kingsmead Park & 5 & Macpherson-Grant in Greatorex 2005, 77 \\
\hline 42 & Kemsley & Sittingbourne Northern Relief Road & 1 & G. Dawkes pers. comm. \\
\hline 43 & Sheerness & Power Station Road & ? & Philp 2002, 194 \\
\hline 44 & Eastchurch & Kingsborough Farm & 9 & Allen et al. 2008, $285 \& 294$ \\
\hline 45 & Sturry & Milner's Pit & 1 & British Museum unpublished \\
\hline 46 & Chislet & Highstead & 16 & Macpherson-Grant in Bennett et al. 2007, 267-8 \& fig. 153 \\
\hline 47 & Monkton & Monkton Court Farm & 1 & Perkins et al. 1994, 243 \& fig. 4.1 \\
\hline 48 & Ramsgate & Harbour Approach Road & 1 & B. Mcnee pers. comm. \\
\hline 49 & Deal & Mill Hill & 2 & Stebbing 1934; British Museum unpublished \\
\hline 50 & Grays & William Edwards School & 1 & Tyrrell in Lavender 1998, 30 \\
\hline 51 & Chadwell St Mary & Mill House Farm & $30+$ & S. Egan \& A. Peachey pers. comm. \\
\hline 52 & Mucking & South Rings area & 261 & $\begin{array}{l}\text { Jones \& Jones 1975, fig. } 48,8 ; \\
\text { Jones \& Bond } 1980,475 ; \\
\text { C. Evans pers. comm. }\end{array}$ \\
\hline 53 & Mucking & North Ring & $16 \mathrm{~kg}$ & Bond 1988, 39 \& fig. 27,49 \& fig. 35 \\
\hline 54 & Basildon & Nevendon Washlands & 1 & Raymond in Gilbert et al. 2013, 159-60 \\
\hline 55 & Broomfield & Windmill Field & 5 & Major in Atkinson 1995, 20 \\
\hline 56 & Springfield & Springfield Lyons & 162 & Major in Brown \& Medlycott 2013, 123 \& fig. 3.39 \\
\hline 57 & Springfield & Springfield Park & $6 ?+$ & Every in Manning \& Moore 2003, 31 \& fig. 7, 1 \\
\hline 58 & Springfield & A12 Boreham Interchange & 5 & Tyrrell in Lavender 1999,19 \& fig. $2.7,2$ \\
\hline 59 & Boreham & Great Holt's Farm & 1 & Major in Germany 2003, 159 \\
\hline 60 & Witham & Ivy Chimneys & 1 & Turner 1999, 193 \& fig. 124 , no. 6 \\
\hline 61 & Great Totham & Howell's Farm & 10 & Major in Wallis \& Waughman 1998, 162 \\
\hline 62 & Heybridge & Crescent Road & 2 & Jones in Wickenden 1986, 33 \& fig. $15,36-7$ \\
\hline 63 & Heybridge & Chalet Site, Hall Road & $2 ?+$ & Peachey in Newton 2008, 97 \\
\hline 64 & Maldon & Lofts Farm & 25 & Major in Brown 1988, 280 \& fig. 22 \\
\hline 65 & Heybridge & Basin Marina & 1 & Brown \& Adkins 1988, 246 \& fig. 11,12 \\
\hline 66 & Rochford & Southend Airport & $1+$ & Bennett 1997, 213 \\
\hline 67 & Rochford & Marshall's Farm & & K. Crowe pers. comm. \\
\hline 68 & Southend & Milton Hall Brickfield & ? & Wymer \& Brown 1995, 177 \\
\hline 69 & North Shoebury & & 135 & Wymer \& Brown 1995, 125-7 \\
\hline 70 & Barling & Gravel Pit & 2 & Crowe 1982 \\
\hline \multirow[t]{2}{*}{71} & Great Wakering & & ? & Wymer \& Brown 1995, 177 \\
\hline & La Panne (Belgium) & & ? & Rahir 1930 \\
\hline
\end{tabular}

Sites are listed in approximately west to east order as far as east London, then sites south of the Thames followed by those north of the river. Quantities are in numbers of fragments, except for Home Farm, Laleham, and Mucking North Ring, which are by weight. Site numbers correspond with those in Figure 2. 
as 'slabs', 'tablets', or 'tiles'. The term adopted here is 'plates', in line with a recent suggestion (Poole in Simmonds et al. 2011, 138 \& 265), more in keeping with modern practice and following the established terminology of 'oven plates' for somewhat similar objects from other periods. Detailed references for the finds are given in Table 1, and these will not be repeated in the text, unless required for some specific point.

\section{FORM}

There are fewer than ten examples that are complete or nearly complete, compared to many hundreds of fragments, but they are enough to demonstrate the characteristic features of this artefact type (Fig. 1). Most examples are found as small fragments with sufficient of the features of shape and perforation surviving to allow their correct identification; even very small fragments with evidence of characteristic features may be identified with some confidence, as at Crescent Road, Heybridge, or Thorpe Lea Nurseries, Egham, but it is possible that other small fragments without such clear evidence have been recovered but gone unrecognised among other assemblages of pottery or fired clay. Though varying somewhat in size, the vast majority of the known examples exhibit a marked similarity in form.

The plates are roughly rectangular in shape; corners are sometimes sharply defined, but more often slightly rounded. A small number of fragments have a more oval shape; this form seems to dominate the assemblage from Queen Mary's Hospital, Carshalton, though other examples are known from Home Farm, Laleham, Heathrow Terminal 5, and the Darenth A2/ A282 Improvement Scheme. Although most examples, where the full form can be reconstructed, show straight or slightly convex sides, some of the examples from Queen Mary's Hospital, Carshalton, show a semi-circular notch in the centre of one of the short sides, a feature known also in one example from the A2/A282 Improvement Scheme at Darenth in Kent. Its function is obscure, but may have been to fix the plate firmly in place in some larger structure.

The smallest known example is one from Yiewsley, measuring $145 \times 135 \mathrm{~mm}$; two others from the same site are slightly larger, at $150 \times 145 \mathrm{~mm}$. The largest known are from Queen Mary's Hospital, Carshalton, where two nearly complete examples measure approximately $220 \times 190 \mathrm{~mm}$. Other near-complete examples from Mucking North Ring, North Shoebury, and Dagenham
Heathway fall within these limits, with roughly the same proportions. A complete example found at Frindsbury, Kent, in the 19th century was illustrated without a scale. The plates vary in thickness from about $15 \mathrm{~mm}$ to $30 \mathrm{~mm}$, but the vast majority are about $20 \mathrm{~mm}$ thick. The edges are in general roughly rounded, although some examples show a more clearly defined profile, with a squared or sloping edge. Some pieces show a groove along one edge, discussed further below.

The plates are perforated by a number of roughly circular holes, formed by an implement such as a stick before firing, though it is also suggested that some may have been formed round a circular core; diameters are in the range $13-40 \mathrm{~mm}$, but typically $15-20 \mathrm{~mm}$. The perforations are usually formed from one side, creating a ridge around the hole on the other side of the plate, though this is sometimes smoothed off. The pattern of perforations can only be discerned on the more complete examples. Some are regularly geometric: examples similar to the arrangements on modern dice are known for four (Frindsbury and Queen Mary's Hospital, Carshalton), five (Yiewsley), and six (North Shoebury) holes. One of the plates from Yiewsley showed seven holes, in two rows of three with one central; at Caesar's Camp, Heathrow, an incomplete example showed a row of two and a row of three holes and, if symmetrical, would have had another row of two; the original object from Kingston Hill shows eight perforations, in two rows of four. The fragment from Heybridge Marina shows at least ten perforations. Other examples seem to have a more irregular pattern of perforations, as at Queen Mary's Hospital, Carshalton, perhaps correlated with the more rounded shape of the complete plate. As the number of perforations increased, so the plates became more fragile. Mean fragment weight, where figures are available, tends to be in the range 40-50 g.

There are few signs of manufacturing technique, other than the smoothing of the perforation ridges mentioned above. Some fragments show signs of finger-tip impressions and most of the plates seem to have been formed simply by hand, though one example from Queen Mary's Hospital, Carshalton, shows signs of having been shaped by a knife. The plates appear to have been roughly shaped from a ball of clay; some are clearly thinner at the centre and thicker around the edges, as though formed by pressure from the centre. One example from Mucking North Ring shows impressions of wattle-work on one surface; this seems most likely to be the result of the 
T. Champion. FOOD, TECHNOLOGy \& CULTURE: LbA PERFORATED CLAy PLATES
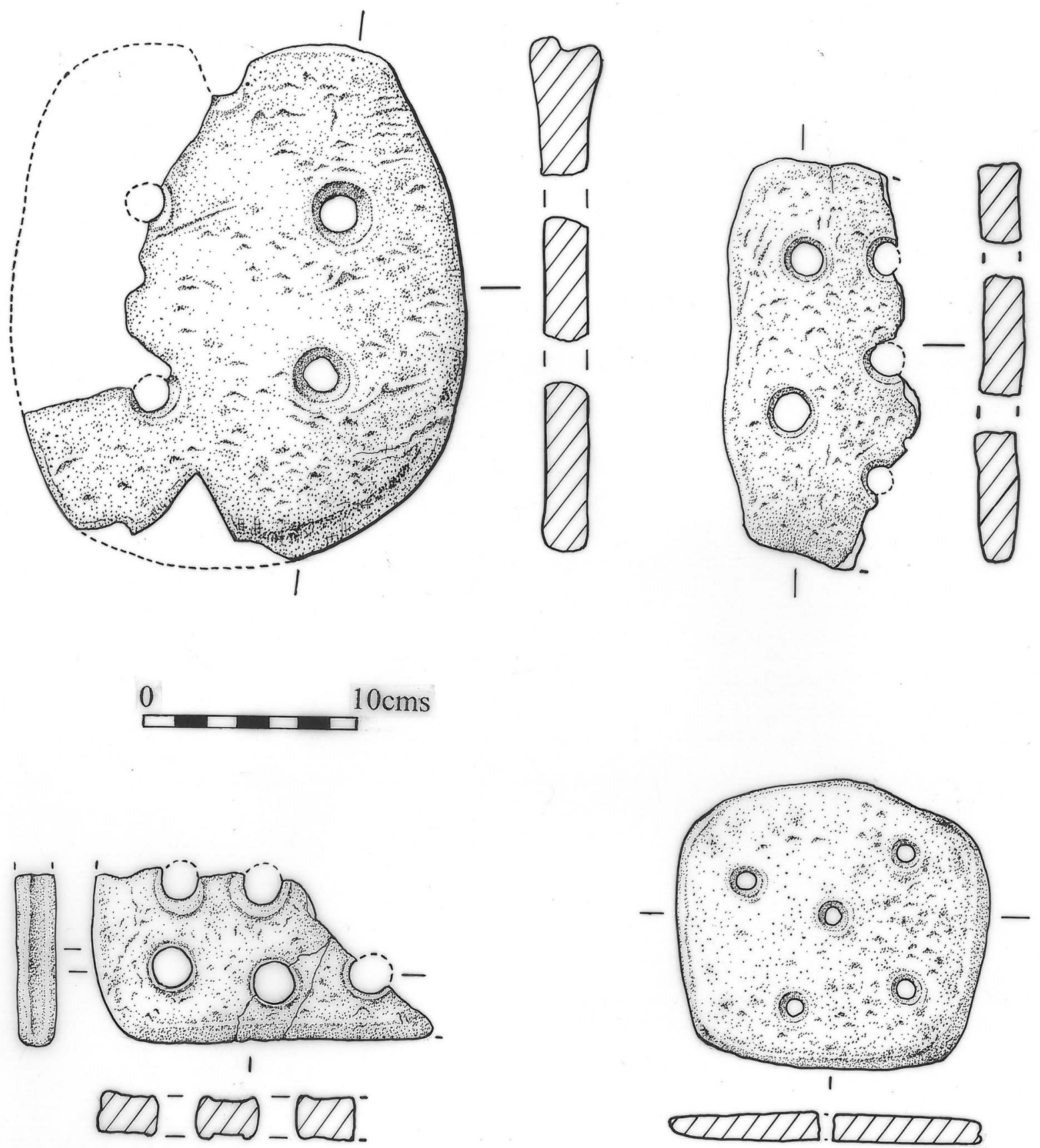

Fig. 1.

Perforated plates from (top left) Queen Mary's Hospital, Carshalton (after Adkins \& Needham 1985, fig. 12); (top right) Caesar's Camp, Heathrow (after Grimes \& Close-Brooks 1993, fig. 25, 17, fig. 25, 17); (bottom left) Mucking North Ring (after Bond 1988, fig. 27, 1); (bottom right) Yiewsley (after Champion 1980, fig. 8) 
surface on which the plate was formed rather than a structural fixing. Some examples are more carefully finished: fragments from North Shoebury are characterised by one surface (the 'top') being slurried to produce a smoother finish, while the other surface (the 'bottom') was profusely gritted, a feature also noted at Queen Mary's Hospital and Westcroft Road, Carshalton; this feature recalls the heavily gritted exterior surfaces seen on the bases of some pots in the Late Bronze Age and Early Iron Age.

One recurring feature of the plates is the presence of a more or less pronounced groove along one or more edges, usually along one of the long sides; at Queen Mary's Hospital, Carshalton, and Mucking North Ring the groove occurs in the short side. This may have been a functional trait, perhaps allowing the plates to be fixed into some larger structure or enabling them to be used in multiples, rather like modern tongue-and-groove boarding, to form a larger area, although the more rounded shape of some examples might make this unlikely. Alternatively, it may be a product of their manufacture, perhaps being formed against a framework of rods to shape one or more sides of the object; or again, it may have resulted accidentally from the plate's being flattened on one side and then turned and flattened on the other.

Apart from these variations in general shape, presence and location of the edge groove, presence or absence of a notch, and the number of perforations, there are few other variants to the standard form. One fragment from Westcroft Road, Carshalton, has been interpreted as the end of a narrow bar with a single row of perforations. Another fragmentary example from Dartford Football Club has been reconstructed as part of a small strip with two perforations, though it might possibly be the corner part of a larger plate with a notch.

\section{FABRIC AND USE-WEAR}

The plates are generally made from a fabric with a sandy matrix and a tempering of crushed flint, occasionally incorporating other temper, and very often indistinguishable from a fabric used for pottery at the same site. The flint is often finely crushed, though examples with much coarser flint grains are known; quantities are mostly sparse, though again examples with much denser quantities are known. The only other fabric used was one with a similar sandy matrix and a vegetable temper. This was particularly common in Essex, at sites around Chelmsford and also at Mucking North Ring on the Thames Estuary, but is also found occasionally elsewhere.

The fragmentary nature of many of the finds has undoubtedly made their detailed study more difficult, but it is noticeable how few comments there are on any visible signs of use-wear by the various specialists who have studied and published these objects. In the original publication of the plates from Queen Mary's Hospital, Carshalton, Robarts (1905, 394 \& 6) described them as 'all very much burnt' and 'very thoroughly burnt', although it is not clear whether he was referring to evidence of manufacture or of use. Elsewhere, there are only very occasional mentions of signs of burning: at Mucking North Ring it was specifically noted that few of the many examples were burnt (Bond 1988, 39), while the lack of signs of burning was also remarked at Caesar's Camp, Heathrow, and other sites (Grimes and Close-Brooks 1993, 354) and also at Home Farm, Laleham; at Hurst Park, East Molesey, it was reported that none of the fragments showed signs of having been exposed to high temperatures (Laidlaw in Andrews \& Crockett $1996,92)$. Visual inspection of plate fragments from a number of other sites by the author suggests that few, if any, examples show signs of wear, discolouration or encrustation that might arise from use rather than from manufacture or post-depositional processes. The evidence, if broadly consistent, is anecdotal rather than systematic, and the question would be worth further research, perhaps through the analysis of a large collection from a single site in direct comparison with the contemporary pottery assemblage.

\section{DISTRIBUTION}

The distribution of the plates is shown in Figure 2. They are, with a few exceptions, confined to the middle and lower Thames valley below Runnymede and show a markedly riverine and coastal distribution along the Thames and its estuary, and in the valleys of some of its tributaries such as the Wandle and the Lea. There are also finds from two regions lying respectively to the north and south of the mouth of the Thames, both of which are themselves riverine. One of these consists of clusters of sites around the estuary and lower valley of the River Backwater at Heybridge, Essex, and in the valley of its tributary River Chelmer, near Chelmsford. The other is a group of sites in east Kent, around the River Stour and the Wantsum 


\section{T. Champion. FOOD, TECHNOLOGy \& CULTURE: LbA PERFORATED CLAy PLATES}

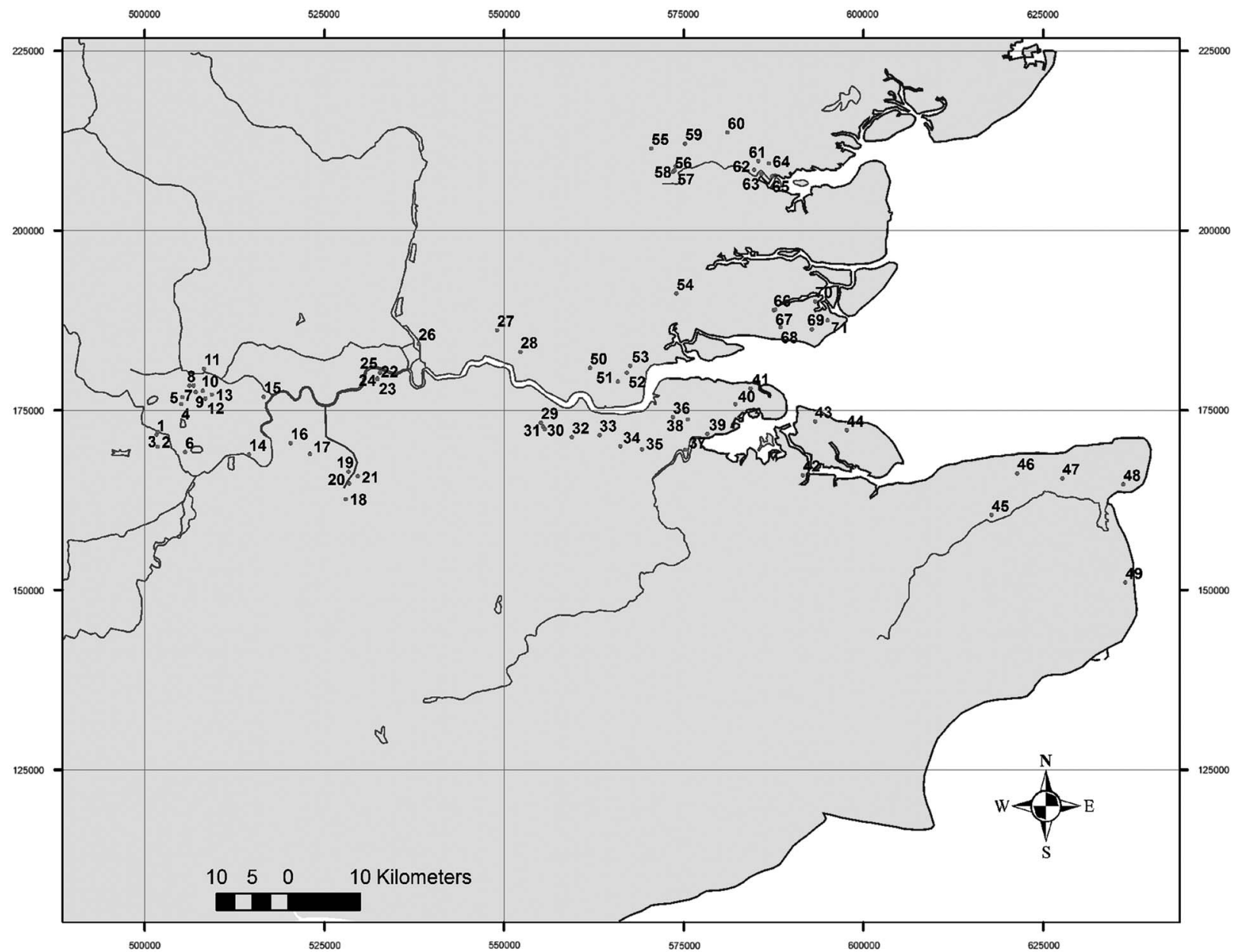

Fig. 2.

Distribution of sites with perforated clay plate fragments, numbered as in Table 1 (La Panne, Belgium, not mapped)

channel, stretching as far south as Deal. The most distant findspot is at La Panne (De Panne), a coastal site in Belgium very near the French border.

Two sites further upstream in Berkshire, at Moulsford and Pingewood, were wrongly included in an early attempt to map the distribution (Champion 1980, fig. 9); this was based on misunderstanding by the author, and further information, including publication (Johnston 1983-5), has now made it clear that there were no finds of this type at these sites, which should therefore be removed. There is also a possible additional example of this type of plate from Reading Business Park: this small fragment of fired clay with a perforation was originally published as a fragment of a loomweight (Bradley \& Hall in Moore \& Jennings 1992, 87 \& fig. 52, 1), but subsequently reinterpreted as a possible perforated plate fragment (Barclay in Brossler et al. 2004, 94), together with a further possible plate rim fragment.

Within this zone, the distribution of plates is somewhat uneven. The number of fragments found on each site varies considerably, and this will be discussed further below. At a larger scale, the plates are most common in southern Essex and northern Kent, where several of the largest assemblages occur. They are less frequent further west, and, despite many findspots, there are only two sites with large assemblages west of central London.

\section{CHRONOLOGY}

Some of the older finds understandably have very limited contextual information and hence cannot be 
reliably dated. Thus, Frindsbury, Yiewsley, and Coombe Warren, Kingston, for example, all have vague Late Bronze Age associations, but no certain contexts; finds from early excavations at Queen Mary's Hospital, Carshalton and Mill Hill, Deal, certainly belong in the final stages of the Bronze Age, though greater precision is impossible. Contextual evidence improves with examples that have come from more recent excavations. There are no finds from contexts with classic DeverelRimbury associations or dates. Perhaps the earliest suggested example is that from Thorpe Lea Nurseries, Egham, found in a pit with a small assemblage of pottery and assigned to the Middle Bronze Age on the grounds of that association and its location near other, more securely dated features. This comparatively weak evidence for a Middle Bronze Age beginning is in contrast to many other sites which have firm associations with pottery which can be assigned to the Post-DeverelRimbury plainware phase of the Late Bronze Age, between 1100 and 800 BC (Barrett 1980; Needham 2007). These include Runnymede and Petters Sports Field, Egham; Caesar's Camp and Terminal 5, Heathrow; the Southwark sites; Olympic Park; and Tollgate, Cobham Golf Course, the Isle of GrainShorne Pipeline sites, Hoo St Werburgh, the Dartford Football Club site, and the A2/A282 Improvement Scheme, Darenth, all in Kent; and Springfield Lyons in Essex. At South Hornchurch, the plates are found in contexts dating to Phases 2 and 3 of the site sequence, which extends from the plainware phase into the succeeding decorated ceramic phase, equivalent to the earliest Iron Age. At Monkton and Highstead the ceramic associations would again suggest the possibility of a date in the decorated phase.

There are no clear associations with pottery of the Early Iron Age. The example from Ivy Chimneys, Witham, Essex, came from a disturbed context; although no Late Bronze Age phase was recognised at the site, where the main occupation began in the Middle Iron Age, it is possible that there had been an earlier phase of activity with artefacts redeposited in later contexts. The finds from La Panne in Belgium came from early excavations and are without secure context; reappraisal of the site suggests that, although activity may have started in the earliest phase of the Iron Age, the bulk of the ceramic and metalwork evidence is consistent with a date from Early La Tène onwards (Kerger 1999).

The plates can therefore be most securely dated to the final phase of the Bronze Age and the very beginning of the Iron Age. How early they started is not yet clear. It is possible that they continued throughout the plainware ceramic phase and somewhat later, thus spanning a period of perhaps $1100-700 \mathrm{BC}$; the main period of their use may also have been much shorter, towards the end of this phase.

\section{LATE BRONZE AGE CONTEXT}

The distribution of the plates merits further discussion to place them in their Late Bronze Age context. It is strongly correlated with the density of evidence for field systems of the later Bronze Age and the patterns of deposition of metalwork. The correlation between the distribution of fields and metal has already been discussed by Yates $(2007,112-20)$. In Kent, the distribution of the plates closely matches the pattern of fields and bronzes in the north of the county: this is concentrated around the Isle of Thanet and the Wantsum in the north-east and in the Isle of Sheppey, around the Medway, and the Hoo peninsula in the north-west. In Essex there are notable concentrations of evidence for fields and bronze deposits around the Blackwater and in the area around Southend, both matched by finds of plates (ibid., 73-7).

The valleys of two tributaries of the Thames are also conspicuous for their concentrations of metalwork and land division, the River Lea (ibid., 114 \& fig. 12.4) to the north and the River Wandle, especially its upper reaches, to the south (ibid., 114 \& fig. 12.5). The Lea valley has so far only produced a single findspot of plate fragments at the Olympic Park site, but to the south there is a cluster of sites in the upper Wandle valley around Queen Mary's Hospital, an area notable for its unusual deposits in addition to the metalwork (Proctor 2002).

There is much less evidence for fields in central London, possibly because of the more restricted nature and scale of excavations, but the findspots of plates in Southwark correspond to a notable cluster of sites with evidence for Bronze Age activity including cultivation (Yates 2007, 32); they are also close to a concentration of bronze objects from the Thames and more especially from sites on the north bank: 'what is eye-catching is the great cluster of land finds that has appeared in the area of the City' (Needham \& Burgess 1980, 455).

There are a number of further sites, albeit mostly with a comparatively low density of plate fragments, on the western outskirts of London, from Kingston to 


\section{T. Champion. FOOD, TECHNOLOGY \& CULTURE: LbA PERFORATED CLAY PLATES}

Egham, many of them within the large area of fields found on the west London gravel terraces (Yates 2007, 32-6), such as those at Heathrow Terminal 5 and neighbouring sites.

These geographical patterns of Late Bronze Age activity have mostly been revealed by modern development-funded archaeology, and are therefore influenced by modern social and economic factors as well as past reality. To what extent the blank areas were really unoccupied, or only minimally exploited, at that time is still uncertain. Yates's methodology was designed to include fieldwork reports where no Bronze Age features were identified, thus suggesting genuinely blank areas, but there are other parts of the lower Thames valley where comparatively little fieldwork has taken place because of the nature of modern landuse and development, for example in the suburban and parkland areas of much of south-western London.

Within this lower Thames region, however, the distribution is not even, and there is considerable variation in the number of plates or fragments found at each site. Quantitative comparison by site is clearly problematic as numbers will be determined by many factors such as post-depositional history, scale of excavation, recovery strategy, and recognition in postexcavation processing, as well as original usage and deposition. Nevertheless, there are striking variations in quantities of plates recovered. Most sites have produced fewer than ten fragments; only 13 sites have produced more than 15 fragments. In seven cases these are known Late Bronze Age defended enclosures or ringworks, the type of site that Yates $(2007,18)$ has called 'aggrandised enclosures': Springfield Lyons, Lofts Farm, Mucking North Ring and South Rings, South Hornchurch, Highstead, and Queen Mary's Hospital, Carshalton. The exceptions are North Shoebury, where 133 fragments were recorded in rescue excavations, and where the nature of the Late Bronze Age occupation was uncertain; Chadwell St Mary; the Beddington Sewage Works site near Queen Mary's Hospital, Carshalton; and Hurst Park, East Molesey, Surrey. There are also two sites, Home Farm, Laleham, and Isle of Grain-Shorne Pipeline Site H, where quantities have been affected by the discovery of large concentrations in specific contexts. It is possible that the aggrandised enclosures have attracted a larger scale of excavation than some of the smaller sites, thus affecting the quantity of finds, or that large deposits have been missed in small-scale excavations, but it is noticeable that even extensive areas of Late
Bronze Age landscape have produced few examples, such as the 47 ha examined at Heathrow Terminal 5, which produced only three fragments. It is quite possible, therefore, that the apparent concentration of finds on such exceptional sites is a real association and a reflection of the density or frequency of the activity that produced and used them. This suggested correlation with defended enclosures will be discussed further below.

\section{FUNCTION}

Since the original discussion of these objects in 1867 , the question of their function has been dominant, but not satisfactorily resolved. Authors have seen them as objects with a mechanical or technological function, and no suggestions have been made about possible ornamental or symbolic uses or other non-utilitarian values. In view of the basic materials used, the simple technology of production, their lack of decoration, and fragile nature, and (at least to modern eyes) their comparatively unprepossessing nature and appearance, this may not be unreasonable. Though individual objects may have been invested with particular significance, it seems likely that his would have been derived from the social context of use. In the following discussion, the concept of their function is therefore viewed in a strictly utilitarian fashion.

The plates are clearly different from other types of perforated object sometimes found in later prehistoric assemblages. They are flat plates rather than vessels, and therefore unlike the pottery bowls with perforated bases known from Iron Age contexts, where the perforations are, in any case, generally somewhat smaller. Perforated plates were also used for tablet weaving. They are not common finds in Britain (Cunliffe 2005, 487 \& fig. 18.1, 24), but are known more widely in western Europe (eg, Grömer 2010, 107-12), most frequently in bone but occasionally in fired clay (eg, Castillo Rollán 1996). They differ from the plates under consideration here, however, in a number of ways: in size and weight, being generally much smaller, thinner and lighter; in shape, being regularly symmetrical, typically triangular or square, rarely rectangular; and in the location of the perforations, which are few in number and placed near the edges or vertices of the tablet and perhaps centrally.

A number of different functions have been suggested for these plates: Robarts $(1905,394)$ suggested use in a 'movable kiln for pottery making' or alternatively that 
they 'may have been used when cooking'; other suggestions have included 'some kind of ventilator' (VCH Middlesex, I, 57, fn 98), 'primitive hotplates' (Jones \& Jones 1975,141$)$, use in controlling a bonfire for firing pottery (Adkins \& Needham 1985) or in metal-working (Perkins et al. 1994), or as a part of an oven or furnace, whether for firing pottery (Rahir 1930) or for cooking food (Bradley 2007, 210), more specifically for baking (Andrews \& Crockett 1996, 101), or as part of the process of making salt (Riehm 1962, 387; Jones \& Bond 1980, 475; Kerger 1999), or in a multifunctional kiln (Poole in Simmonds et al. 2011, 265). Two authors have suggested and illustrated quite specific uses: Perkins has argued for their use to improve air supply in metal-working furnaces for melting bronze (Perkins et al. 1994, 311-2 \& fig. 33), while Rahir reconstructed a perforated plate with pedestals inserted into the perforations to support a vessel during pottery firing (1930, fig. 7).There is general agreement that the plates were meant to allow the passage of air for some purpose, rather like modern air bricks; the holes are much larger than those used for liquids, as in modern strainers and colanders. A more precise interpretation of their function or functions will depend on additional evidence, such as discovery in a primary structural context; fabric and use-wear; distribution; depositional contexts and associations; and typological and technological parallels. Since no example of a plate has yet been found in a structural or functional context clearly showing its method of use, the first of these lines of argument can be quickly dismissed. The evidence for fabric and use-wear has been described above, where it was suggested that few, if any, of the objects bear significant marks derived from usage.

The estuarine distribution of the plates might suggest a connection with the salt-working industry, which can be documented in the Late Bronze Age at relevant sites in the Thames estuary such as Mucking (Barford 1990). Plates and salt briquetage are found at North Shoebury, Mucking North Ring, South Hornchurch, Highstead, Isle of Grain-Shorne Pipeline sites, Hoo St Werburgh, Cobham Golf Course, Northfleet, and at La Panne in Belgium. Nevertheless, it seems unlikely that there was a functional relationship between the plates and salt production, for two major reasons. First, much of the fired clay used in salt production has a characteristic dark red, purple, or even lavender surface colour, sometimes with a white or cream encrustation. None of the plate fragments so far inspected shows any sign of these features.
Secondly, some of the sites producing plates are too far from the salt water of the estuary to have been realistically the location of salt production. It is true that at Mucking at least some stages of the salt production, or the production of fired clay artefacts for use in this process, took place some distance inland and uphill from the water's edge (Jones 1977), and the same phenomenon has been noted for some of the HS1 sites in Kent (Booth et al. 2011, 216-7), but these distances are small compared to the distances between some of the other sites producing plates and the contemporaneous existence of salt water. Modern perceptions of the Thames separate a marine zone (ie, salt content above 30 parts per thousand) from a brackish one (salt content in the range 0.5-30 parts per thousand) at around Dartford, with freshwater conditions above Battersea. Even allowing for variations in salinity in prehistory, it seems highly improbable that the Surrey and west London sites from Kingston to Egham would have been within suitable distance of salt water; remains of prehistoric salt-working have not been reported higher up the Thames estuary than at South Hornchurch (Guttman \& Last 2000, 344 \& fig. 18.2). A third reason may also be offered from an analysis of the more specific contextual locations and associations at Mucking North Ring, where it was noted that 'there was little correlation between the distribution of this material and the debris of salt manufacture' (Barford in Bond 1988, 50) A role in salt-working can therefore be excluded.

Another recurring association is with metal-working, as at Springfield Lyons (Needham \& Bridgford in Brown \& Medlycott 2013, 47-74), Mucking North Ring (Bond 1988, 21-2 \& fig. 14), South Hornchurch (Guttman \& Last 2000, 344 \& fig. 19), Mill Hill, Deal (Champion 1980, 237 \& fig. 5.6), and Highstead (Bennett et al. 2007, 258-65 \& figs 148-51). Whether they would have been used in the smelting of copper or, more probably, in the heating of crucibles to melt the bronze alloy, it seems likely that the temperatures necessary would have caused far more surface modification to the plates than has been evidenced anywhere. The recurring comments on the comparative lack of the expected marks of burning seem to rule out their use in such processes. Nor has any fragment yet been claimed to exhibit surface traces of metal droplets. The associations with metalworking seem mainly restricted to some of the aggrandised enclosures, and it is noticeable that other sites, such as Heathrow Terminal 5, have produced no evidence of metalworking, despite extensive excavation. 


\section{T. Champion. FOOD, TECHNOLOGY \& CULTURE: LbA PERFORATED CLAY PLATES}

The same argument about temperature would also probably rule out any role in the production and firing of pottery. Structures incorporating perforated clay plates have been claimed as pottery kilns in other parts of western Europe in the Late Bronze Age (eg, Audouze \& Büchsenschütz 1991, 138-9). If this interpretation is correct, they seem somewhat larger than the plates being considered here; the example from Sévrier, Haute Savoie, France, was $0.6 \mathrm{~m}$ in diameter. It is true that we do not know the full size or form of the structure into which the plates were fitted, but they still seem rather small for elements of pottery kilns. In any case, with the benefit of more recent research we can rule out Rahir's suggested reconstruction of their use as supports in a kiln at La Panne (1930, 21 \& fig. 7). The pedestals he shows inserted into the perforations of a plate, as well as other items of fired clay, would now be recognised as components of salt-working briquetage (Kerger 1999, 78), well documented in northern France (Prilaux 2000, 74-7) as well as southern (eg, at Mucking North Ring; Barford in Bond 1988, 39-41) and eastern England (Lane \& Morris 2001, 370-2; Morris 2007, 430-2). Salt was clearly being extracted from sea-water at $\mathrm{La}$ Panne, as at sites in the Thames estuary, but not with a technology incorporating perforated plates.

A recurring association of the plate fragments is with burnt material. At Queen Mary's Hospital, Carshalton, Robarts noted that they were found with deposits he interpreted variously as hearths (1905-6, $149)$ or as cremation deposits $(1905,397)$. More recent excavation reports have been more specific. At the A2/A282 Improvement Scheme fragments of perforated plates were found in a pit with a charcoal-rich fill and in a hollow containing a large deposit of burnt flint, possibly the remains of a redeposited burnt mound (Simmonds et al. 2011, 69 \& 137). At the Dartford Football Club they were found with carbonised seeds and grain and burnt bone, as well as fired clay interpreted as structural oven daub (Poole in Simmonds et al. 2011, 265). At Tollgate, fragments were found in a pit with charcoal, burnt gravel, and fire-cracked flint (Bull 2006, 11). The same association with burnt flint was found at Hoo St Werburgh and at Isle of Grain-Shorne Pipeline Site H. Whether the burnt flint and the perforated plates were used in the same activity, or were deposited in association with each other after different activities, is not clear. Evidence from Hurst Park, East Molesey, is more illuminating: two clusters of Late Bronze Age activity were located, c. $75 \mathrm{~m}$ apart but probably contemporary. They were associated with very different artefact assemblages: one comprised many pits filled with burnt flint in an ashy matrix, while the other contained perforated clay plates, quern fragments, and cereal remains. As the excavators suggest, the most likely explanation is that the structures and associated features represented the locations of 'two different but related activities', perhaps boiling and baking (Andrews \& Crockett 1996, 64-9 \& 101-2). If this is true more generally, then it seems likely that the association with burnt flint arises not from use in the same activity, but from deposition in the same context of the debris from two different, but possibly related, activities involving the use of fire.

In view of all this evidence, these plates must have been used in some sort of oven or furnace, but at a lower temperature than required for metal or ceramics. The most likely function would seem to be for cooking. This suggestion is also supported by a consideration of the most relevant typological parallels. The Late Bronze Age plates appear to have no obvious predecessors and therefore may have been invented for a new technological process. They also appear to have no immediate successors. The nearest thing to a technological successor, whether a direct typological descendant or an independent invention, would be the perforated oven plates known from a number of Iron Age sites. They are well documented at Danebury: the Type 1 plates (Cunliffe \& Poole 1991, 146-9 \& fig. 4.95, 27-9) are circular rather than rectangular, and much larger than the Late Bronze Age plates, being $0.3-0.45 \mathrm{~m}$ in diameter and $20-160 \mathrm{~mm}$ thick with perforations $15-80 \mathrm{~mm}$ wide; their function as oven plates is confirmed by close association with oven bases. Similar oven plates have also been found at Maiden Castle (Wheeler 1943, 321 \& pl. xxxvii; Poole in Sharples 1991, 209 \& fig. 168, 2-6 \& 8), though they are smaller and more varied in shape than those at Danebury. A different form, possibly with a different but related function, is characterised by a circular clay plate with a large circular perforation surrounded by smaller holes; this is Type 2 at Danebury (Cunliffe \& Poole 1991, 149 \& fig. 4.95, 30), but also known at other sites such as Gussage All Saints (Wainwright 1979, fig. 78, 4057), Little Woodbury (Brailsford 1949, 159 \& fig. 2), Fengate (Pryor 1984, 166-8 \& fig. 19), and Haddenham (Lucas in Evans and Hodder 2005, 92-3). Both of these types seem to have a function as oven parts, but their precise 
chronology in the Iron Age is not totally clear, as is their relationship to the perforated plates discussed here. There may well be a considerable chronological gap between them. Most discussion of the usage of the plates has been based on the assumption of a single function. It is quite possible, of course, that such ovens were multi-functional, rather than just for food preparation. In any case, there may have been close links between the various pyrotechnologies, with parallel advances in the use of kilns and ovens for food, pottery, and other purposes.

Until an example of an oven with small perforated plates is found in a relatively well preserved structural condition, the precise way in which these plates worked will remain obscure. The use of a perforated plate puts these ovens in the tradition of so-called 'white' ovens, in which the fire chamber is separated from the cooking chamber, as distinct from the 'black' ovens, in which the fire is lit on the floor of the cooking chamber and often raked out before the insertion of the food to be cooked. The Iron Age ovens of Danebury Type 1 discussed earlier are of the same basic form, though the black oven tradition seems to have dominated in later periods, such as for medieval and later bread and pizza ovens; versions of the white oven tradition are perhaps more familiar archaeologically as pottery kilns, for example those of the Roman period where the furnace chamber is separated from the oven by a raised oven floor, which could be constructed in a variety of techniques, including bars and plates (Swan 1984, 29-41).

How the perforated plates of the Late Bronze Age fitted into such an oven is unclear: if the identification of the fragments from Westcroft Road, Carshalton and Dartford Football Club as parts of narrow bars is correct, their precise function in such an oven is even more problematic. As noted above, the plates are quite small, but they need not have made up the entire floor of the oven, and in some cases they may have been used in multiples, though this would have been difficult with the more rounded examples. This suggested usage would presumably have required some sort of chamber for the fire below the plate, perhaps set on a base or hearth, as with the Danebury Type 1 ovens. Unfortunately, the sites of the Late Bronze Age so far excavated in the lower Thames region have shown remarkably little evidence for features such as hearths. The precise relationship of the plates to the fire and the nature of the fuel used are unknown, so it is difficult to assess the apparent lack of obvious signs of exposure to heat. In any case, the temperatures need not have been very high; most modern domestic cooking is carried out at temperatures well below $250^{\circ} \mathrm{C}$. A similar question has been noted for fired clay artefacts of a later period: sites of the Late Iron Age and early Roman period in east London have produced a range of fired clay objects thought to have been elements of ovens or furnaces but showing similarly little sign of exposure to heat (Howell et al. 2011, 70-1). The oven would have been covered by a dome of clay: the discovery on some sites, such as Heybridge Marina and Dartford Football Club, of fired clay fragments interpreted as parts of oven covers therefore supports the interpretation.

\section{FOOD IN THE LATE BRONZE AGE}

The idea that these plates are the remnants of food ovens is not, of course, new. The existence, or perhaps even the innovation, of ovens in the Late Bronze Age has, however, attracted little attention. It is suggested here that the plates represent a fundamentally new technology (ovens) for processing a specific food stuff (spelt) by a new process (baking) to produce a new form of food (bread), and that this innovation was primarily associated with distinctive places of authority or ceremony in the Late Bronze Age landscape.

Spelt (Triticum spelta), now a minority crop grown in limited areas of Europe but enjoying something of a renaissance as a health food, was once much more widespread in the later prehistoric and medieval periods. Like other early varieties of wheat, it required considerable work to separate the grain from the husk, and was progressively replaced by free-threshing wheats such as bread wheat ( $T$. aestivum). It was significantly different from crops that had preceded it such as emmer ( $T$. dicoccum) in its suitability for baking as bread. This is determined largely by the gluten content of the wheat, and in particular by the proportion of glutenins, which are thought to control the strength and elasticity of the dough; this allows the bread to retain the gases released in fermentation and cooking and take on its typical structure and volume. Comparative tests on modern varieties show that emmer had the lowest proportion of glutenins, with bread wheats at the top of the range and spelt in the middle (Wieser 2000); earlier comparisons showed similar results, with emmer judged unsuitable for bread making (LeClerc et al. 1918). These tests, performed on modern varieties of the various wheats and 


\section{T. Champion. FOOD, TECHNOLOGY \& CULTURE: LbA PERFORATED CLAY PLATES}

using modern perceptions of acceptable quality, should be applied to prehistoric wheats with great caution, but it does seem as though spelt would have offered the possibility of different modes of preparation and consumption from those of the varieties that preceded it.

Spelt was regularly cultivated in Europe at least by the Early Bronze Age, with good evidence from the North Alpine area for a date c. 2300 BC (eg, Akeret 2005). Recent research has suggested that the spelt that became common in central and western Europe in later prehistory was not derived from the Near Eastern spelt, but was a separate development, arising from an introgression of a tetraploid wheat (emmer) into a free-threshing hexaploid wheat (bread wheat), a development that may have happened in central Europe in the 3rd millennium BC (Blatter et al. 2004).

Spelt was a key component of the 'Bronze Age agricultural revolution' in Britain (Stevens \& Fuller 2012, 717), which was characterised not just by the increased extent of cultivation and of reliance on cultivated crops, but also the introduction of new crops such as peas and beans as well as spelt. Though spelt may have had other advantages such as its suitability to particular climatic or environmental conditions (van der Veen 1992, 145-6), its potential for allowing wheat to be consumed in the form of bread rather than soups, stews, and porridges may also have been an important factor in its favour.

Cultivation of spelt is now known in Britain from the later part of the Early Bronze Age and several of the earliest records are in fact from sites in the Thames estuary region: the earliest date is from a field system and associated pit at Minster, in the Isle of Thanet, Kent (Martin et al. 2012), while finds from Middle Bronze Age contexts are known at Princes Road, Dartford (Pelling in Hutchings 2003, 71-5), Westwood Cross, Broadstairs (Allison 2005), and Beechbrook Wood (Booth et al. 2011, 172, 4), all in Kent, and at North Shoebury, Essex (Murphy in Wymer \& Brown 1995, 146). Other records of similar date are known from the Middle and Upper Thames Valley (Lambrick 2009, 251).

The spread of spelt cultivation in the later Bronze Age needs more detailed documentation, but we can note occurrences at sites such as Black Patch, Sussex (Hinton in Drewett 1982, 383), and Potterne, Wiltshire (Straker in Lawson 2000, 84-6), as well as in north-eastern England (van der Veen 1992, 73) and the Middle and Upper Thames Valley (Lambrick 2009, 251). In the 1st millennium BC it was grown alongside emmer in much of eastern England; elsewhere, in parts of north-eastern England (van der Veen 1992), in the Upper Thames Valley (Lambrick 2009, 252), and especially in parts of Wessex (Campbell 2000, 46-7), it had been adopted as the principal or only wheat crop by the beginning of the Iron Age. Ultimately both spelt and emmer were replaced by bread wheat (T. aestivum) as the dominant variety in the Roman period, as bread became the regular form in which wheat was consumed.

It is clear that spelt was widely cultivated in parts of England during the Late Bronze Age, and it is quite probable that its potential use for making bread would have been discovered, even if that knowledge was not already transmitted with the crop itself. Spelt has now been identified at a number of the sites that have produced perforated plates and where modern excavation techniques have included the recovery and identification of plant remains. These include Springfield Lyons (Murphy in Brown \& Medlycott 2013, 127-33), Lofts Farm (Murphy in Brown 1988, 282), the Chalet Site, Heybridge (Pelling in Newton 2008, 112), South Hornchurch (Scaife in Guttman \& Last 2000, 346), Kingsborough (Stevens in Allen et al. 2008, 296), Cobham Golf Course (Davies 2006, 4), Queen Mary's Hospital, Carshalton (Scaife in Groves \& Lovell 2002, 18), Runnymede (Gale in Needham 1991, 259), and probably Hurst Park (Hinton in Andrews \& Crockett 1996, 95-8). Such widespread availability of spelt in the area of perforated plate usage supports their interpretation as oven fixtures.

It is also possible that another technological innovation was implicated in this process. Saddle querns have received little attention, but there is a fundamental difference between round forms which acted like a mortar and long forms used with a backwards and forwards motion. Detailed research is still needed, but early querns seem to belong to the rounder forms, while the long form, though known on the continent from the Neolithic, does not appear to have been adopted in Britain until around the middle of the Bronze Age; examples can be seen at Flag Fen, in a context beneath wood dated to 1350 вС (Pryor 2001, 322-8 \& figs 11.6-9). Such long querns would have been capable of producing a much more finely ground flour, better suited to the making of bread. (I am grateful to Professor David Peacock for this information.)

It is clear that during the later part of the Bronze Age the serving and consumption of food took on a more enhanced social significance as witnessed by the 
materialisation of these practices in the archaeological record. New forms of bronze artefacts were produced such as cauldrons (Gerloff 2010) and flesh-hooks (Needham \& Bowman 2005), while the ceramic repertoire was greatly expanded to include a variety of jars, bowls, and small cups, many of which were increasingly decorated (Barrett 1980): 'the preparation and service of food was now achieved using a new range of ceramic vessels suited to the service of food individually' (Barrett 1989, 312). Something of the social context of such consumption can occasionally be glimpsed in such sites as the major middens of Wessex, as at Potterne (Lawson 2000) or East Chisenbury (McOmish 1996), with their evidence for feasting. There has been considerable discussion of the relationship between social authority and exploitation of the agricultural resources, the social practices through which this was negotiated and the material culture which is the physical evidence of these practices (Bradley 2007, 178-225; Yates 2007, 107-32). There has, however, been much less attention paid to what was being consumed, or the social significance of possible foodstuffs.

In this context it may not be surprising, therefore, if a particular crop was endowed with a special significance, especially as it could be processed and consumed in a new way. The concentration of finds on ringworks and other aggrandised enclosures underlines the social significance of such consumption. The function of these sites has been much debated but still remains uncertain: they could be interpreted as the residences of elite members of the social group, or alternatively they could be seen as more communal places for the enactment of important social functions, though these interpretations need not be mutually exclusive (Needham 1992, 52-6; Guttman \& Last 2000, 351-3; Bradley 2007, 206-10). This is not the place to pursue that debate further, but it should be noted that, whatever their social role, there have been repeated suggestions of the practice of significant consumption, or even feasting, at these sites, whether this was based on the deposition of large quantities of fine-ware vessels (Guttman \& Last 2000, 352) or larger jars (Adkins \& Needham 1985, 32-3; Needham $1992,55)$, or deposits of debris derived from feasting (Brown 1988, 271).

In a detailed study of the post-Deverel-Rimbury ceramics of East Anglia, Brudenell (2012, 259-98) has identified patterns of variability in the nature of site assemblages, in particular a group of assemblages (his Type B) dominated by fine-ware bowls and large or very large jars, the material expression of a specific form of social consumption. These assemblages are particularly associated with ringwork enclosures at the end of the Late Bronze Age; they are also found occasionally at open settlements, typically in the form of unusually large ceramic groups of above-average sherd weight from a single context or feature, perhaps representing material deposited soon after a specific social event. The pattern of deposition of the perforated plates seems to match the pattern of such fine-ware ceramic assemblages well: they are found most plentifully at a limited number of sites, especially ringworks, occasionally at other sites in the form of large dumps of material, and at low frequency elsewhere.

This reassessment of the perforated plates has therefore enabled us to confirm the previous suggestions of cooking, and more particularly of baking, as their most likely function. It has also confirmed a special social role for the preparation and consumption of bread, a role especially associated with the ringworks; they have previously been suggested as places of feasting and to that ceramic evidence can now be added the perforated plates and the practice of baking. The new technology can be linked to the exploitation of a variety of wheat, spelt, introduced as part of the agricultural transformations of the 2 nd millennium BC. If the introduction of a new technology, ovens, can be understood in this context, the socially embedded nature of this technology may explain the demise of the tradition at the beginning of the Iron Age: the collapse of the social conditions that produced the strongly defended ringworks also led to the disappearance of related social practices and an associated technology. The perforated plates themselves disappear completely and there are few other signs of ovens in the lower Thames region; how wheat was being consumed in this region in the early Iron Age clearly needs further investigation.

\section{AN ESTUARINE 'MARITORY'?}

Though the function of these plates has attracted most of the attention in recent discussion, another question of great interest has arisen as the accumulation of new finds has reinforced their very marked distribution pattern. As discussed above, this is confined to the lower stretches of the Thames and its estuary and tributaries, and to a very narrow region on either side, but extending across the Channel to Belgium. Stuart Needham has recently coined the term 'maritory' for a 


\section{T. Champion. FOOD, TECHNOLOGY \& CULTURE: LbA PERFORATED CLAY PLATES}

'high-flux sphere of maritime interaction' with a 'set of shared and reciprocal interests' $(2009,19)$. He was, however, primarily concerned with an earlier period of the Bronze Age, and the interaction sphere he discussed was also on a much larger scale than the estuarine region that is the focus here. Indeed, most discussions of maritime interaction involving eastern England have been on a much larger scale. Needham's Early Bronze Age maritory stretches through the Channel and the southern North Sea from Brittany to Denmark, while the concept of an Atlantic Bronze Age extends to an even larger region including Iberia (eg Chevillot \& Coffyn 1991). Such distributions certainly show the possibility of long-distance interaction, articulated through predominantly maritime links, even if we find it difficult to explain the nature of these links or the scale of the interaction sphere.

These larger-scale interaction zones have, however, distracted attention from smaller zones of shared cultural practice. Although the distribution of the perforated plates does extend across the Channel, and is another important element in the picture of contacts across the southern North Sea in later prehistory, the main clustering of activity is in the Thames estuary. Estuaries have attracted little attention as potential zones of cultural interaction, compared to islands (Rainbird 2007) or the land around the open sea (van der Noort 2011), despite a few papers in L'Helgouach and Briard (2001). Even as a river the Thames has received more attention as a corridor of communication along which people, goods, and ideas flowed, than as a means of communication across which people interacted with shared interests and practices. The possibility of the greater Thames estuary as a unified cultural zone was recognised in the development of a single archaeological research framework (Williams \& Brown 1999), though much recent work has been devoted to the long-term formation processes of the river and its valley, and to maritime, inter-tidal and more recent themes rather than to shared cultural practices in prehistory (Heppell 2010). Nevertheless, the distribution discussed here suggests that the river formed the central axis of communication in the lower reaches of the valley. Much of the interaction along the river as well as all of the cross-river contact must have been carried out by boat. This episode of waterborne connectivity coincides with the period when archaeological evidence for boats is most problematic: the start of the period of use of the perforated plates may overlap with the currency of Bronze Age sewn-plank boats but, by its end, the only surviving evidence is for log boats, though others may have existed (van der Noort 2011, 152-69).

The communities, or at least some members of them, living in the estuarine zone clearly shared common practices of food consumption and it is worth investigating whether there is any other evidence for shared cultural practices in this region. For a much earlier period, Whittle et al. $(2011,384)$ noted shared practices in the Early Neolithic north and south of the Thames, though these were parts of much wider regional distributions; they concluded that "whether there was any further kind of "estuary identity" is unclear'. For a much later period, Biddulph et al. $(2012,194)$ have suggested the possibility of a 'wider late Roman economic zone in the Thames estuary'. For the early 1st millennium BC, there are clearly shared practices in settlement, pottery, and metalwork, but these are parts of much more widespread traditions. More detailed research on the ceramic traditions in the region may show more localised patterns of common practice, but at the moment the best evidence is for slightly earlier and later periods. Though the Middle Bronze Age ceramics of the region are as yet little known, it is possible to see some similarities in the fine-wares. A distinctive type of globular bowl with impressed ring and dot ornament, often referred to as a Birchington bowl after an early discovery in the Isle of Thanet with a hoard of palstaves (Powell-Cotton \& Crawford 1924), is now recognised as a regional variant of the globular bowl element in Deverel-Rimbury ceramics of the region, with a distribution in north Kent and southern Essex, for example at Netherhale Farm, (Macpherson-Grant 1992) and Westwood Cross (Gollop 2005), both in the Isle of Thanet, or North Shoebury in Essex (Wymer \& Brown 1995, 78 \& fig. 62, 9). Another form of globular, distinguished by its shape and the presence of a horizontal band of impressed ornament, is also found in Kent, as at Sandway Road (Booth et al. 2011, fig. 4.4, SWR/1) and further west in Surrey, as at Thorpe Leas Nursery, Egham (Hayman et al. 2012, \& fig. 5.29, 24-6). In the Iron Age, Cunliffe's Highstead 2 and Mucking-Crayford ceramic style zones potentially extend across the lower estuary into southern Essex and north Kent (2005, 94, 115 \& figs A:4 \& A:29; 2009, figs 6:10 \& 6:3).

Though these ceramic similarities are not contemporary with the perforated plates, and their geographical distributions do not exactly match that of the plates, they 
suggest a degree of shared cultural practice within the lower Thames estuary, and it is especially significant that they are defined primarily by the presence of decorated pottery, which may have had a material and visible role to play in the service and consumption of food and drink. We may here be seeing another example of what Needham and Bowman $(2005,124)$ have called 'regionally differentiated eating customs' in the later Bronze Age.

\section{CONCLUSIONS}

The accumulation of data over a period of 30 years has allowed a particular artefact type to be much better understood and more meaningfully interpreted. The interpretation suggested here sheds light on the usage of arable crops for social purposes and the significance of food for the articulation of social relations in the Late Bronze Age. Though the original questions were rather limited ones of chronology and function, the quantity and quality of the data now available make it possible to combine artefactual, environmental, structural, and settlement evidence to offer an interpretation of the social context of the preparation and consumption of food in the Late Bronze Age of this region. The remarkable distribution of finds suggests a network of maritime interaction around the lower Thames, which would warrant further investigation; more generally, the role of estuaries in facilitating social interaction could be further explored. Above all, though, the discussion demonstrates the value of the developer-funded archaeology carried out over the last 30 years. The cumulative impact of the work done in the region is significantly greater than the mere sum of each individual project, but that value can only be realised through systematic attempts to synthesise the results, something that has been undertaken all too infrequently.

Acknowledgements: An early version of this paper was given in a research seminar in the University of Southampton and I would like to thank all my colleagues for their (mostly) helpful comments. I would also like to thank all those who have supplied information since the original publication, including: the late Margaret Jones (Mucking Excavations), Nigel Brown (formerly Essex County Council), Peter Couldrey, Ken Crowe (Southend Museum), Sam Egan \& Andy Peachey (Archaeological Solutions), Chris Evans (Cambridge Archaeological Unit), Marit Gaimster \& Frank Meddens (Pre-Construct Archaeology), J. D. Hill \& Jody Joy (British Museum), Matt Leivers (Wessex Archaeology), Louise Rayner, Jim Stevenson, Trista Clifford \& Giles Dawkes
(Archaeology South-east), Barbara McNee, and Rob Poulton (Surrey County Archaeological Unit). Most of the objects discussed are from recent excavations: thanks are due to the various developers who funded the work, the excavation teams who recovered the objects and the post-excavation teams who published them. Figure 1 was drawn by Barbara McNee and Figure 2 by Lyn Cutler. I am grateful to Chris Evans and Nigel Brown for comments on a draft version, and to David Peacock, Matt Brudenell and Yann Lorin for information. I am also grateful to the anonymous referees for helpful comments that have significantly improved the paper, though I am of course responsible for the final result.

\section{BIBLIOGRAPHY}

Adkins, L. \& Needham, S. 1985. New research on a Late Bronze Age enclosure at Queen Mary's Hospital, Carshalton. Surrey Archaeological Collections 76, 11-50

Akeret, O. 2005. Plant remains from a Bell Beaker site in Switzerland, and the beginnings of Triticum spelta (spelt) cultivation in Europe. Vegetation History of Archaeobotany $14,279-86$

Allen, M.J., Leivers, M. \& Ellis, C. 2008. Neolithic causewayed enclosures and later prehistoric farming: duality, imposition and the role of predecessors at Kingsborough, Isle of Sheppey, Kent, UK. Proceedings of the Prehistoric Society 74, 235-322

Allen, T., Donnelly, M., Hardy, A., Hayden, C. \& Powell, K. 2012. A Road Through the Past: archaeological discoveries on the A2 Pepperhill to Cobham roadscheme in Kent. Oxford: Oxford Archaeology

Allison, E. 2005. Environmental archaeology. Canterbury's Archaeology 2003-04, 59-61

Andrews, P. \& Crockett, P. 1996. Three Excavations along the Thames and its Tributaries, 1994: Neolithic to Saxon settlement and burial in the Thames, Colne, and Kennet valleys. Salisbury: Wessex Archaeology

Arnold, A.A. 1887. Roman remains and celt found near Quarry House, Frindsbury. Archaeologia Cantiana 17, 189-92

Atkinson, M. 1995. A Late Bronze Age enclosure at Broomfield, Chelmsford. Essex Archaeology \& History $26,1-24$

Audouze, F. \& Büchsenschütz, O. 1991. Towns, Villages and Countryside of Celtic Europe. London: Batsford

Bagwell, M., Bishop, B. \& Gibson, A. 2001. Mesolithic and Late Bronze Age activity at London Road, Beddington. Surrey Archaeological Collections 88, 289-307

Barford, P.M. 1990. Appendix 2: salt production in Essex before the Red Hills. In A.J. Fawn, K.A. Evans, I. McMaster \& G.M.R. Davies (eds), The Red Hills of Essex: salt making in antiquity, 81-4. Colchester: Colchester Archaeological Group

Barrett, J. 1980. The pottery of the later Bronze Age in lowland England. Proceedings of the Prehistoric Society 46, 297-319

Barrett, J. 1989. Food, gender and metal: questions of social reproduction. In M.L. Sørensen \& R. Thomas (eds), 


\section{T. Champion. FOOD, TECHNOLOGY \& CULTURE: LbA PERFORATED CLAY PLATES}

The Bronze Age-Iron Age Transition in Europe: aspects of continuity and change in European societies c 1200 to 500 BC 304-20. Oxford: British Archaeological Report S483

Barrett, J. \& Bradley, R. (eds). 1980. Settlement and Society in the British Later Bronze Age. Oxford: British Archaeological Reports British Series 83

Bennett, A. 1997. Archaeology in Essex 1996. Essex Archaeology \& History 28, 205-27

Bennett, P., Macpherson-Grant, N. \& Couldrey, P. 2007. Highstead, near Chislet, Kent: excavations 1975-1977. Canterbury: Canterbury Archaeological Trust

Biddulph, E., Foreman, S., Stafford, E., Stansbie, D. \& Nicholson, R. 2012. London Gateway: Iron Age and Roman salt making in the Thames Estuary: excavation at Stanford Wharf Nature Reserve, Essex. Oxford: Oxford Archaeology

Blatter, R.H.E., Jacomet, S. \& Schlumbaum, A. 2004. About the origin of European spelt (Triticum spelta L.): allelic differentiation of the HMW Glutenin B1-1 and A1-2 subunit genes. Theoretical of Applied Genetics 108(2), 360-7

Bond, D. 1988. Excavation at the North Ring, Mucking, Essex. Chelmsford: East Anglian Archaeology 43

Booth, P., Champion, T., Foreman, S., Garwood, P., Glass, H., Munby, J. \& Reynolds, A. 2011. On Track: the archaeology of High Speed 1 Section 1 in Kent. Oxford: Oxford Wessex Archaeology

Bradley, R. 2007. The Prehistory of Britain and Ireland. Cambridge: Cambridge University Press

Brailsford, J.W. 1949. Excavations at Little Woodbury. Proceedings of the Prehistoric Society 15, 156-68

Brossler, A., Early, R. \& Allen, C. 2004. Green Park (Reading Business Park): Phase 2 Excavations - Neolithic and Bronze Age sites. Oxford: Oxford Archaeology

Brown, N. 1988. A Late Bronze Age enclosure at Lofts Farm, Essex. Proceedings of the Prehistoric Society 54, 249-302

Brown, N. \& Adkins, P. 1988. The work of Essex County Council Archaeology Section, 1987: Heybridge. Essex Archaeology \& History 19, 243-8

Brown, N. \& Medlycott, M. 2013. The Neolithic and Bronze Age Enclosures at Springfield Lyons, Essex: excavations 1981-1991. Chelmsford: East Anglian Archaeology 149

Brudenell, M. 2012. Pots, Practice and Society: an investigation of pattern and variability in the postDeverel-Rimbury ceramic tradition of East Anglia. Unpublished PhD thesis, University of York

Bull, R. 2006. The Prehistoric, Roman and Medieval Landscape at Tollgate, Cobham, Kent. York: Archaeology Data Service, CTRL Integrated Site Report Series

Campbell, G. 2000. Plant utilization: the evidence from charred plant remains. In B. Cunliffe (ed.), The Danebury Environs Programme: the prehistory of a Wessex landscape. Volume 1: Introduction, 45-59. Oxford: English Heritage and Oxford University Committee for Archaeology

Castillo Rollán, L.M. 1996. Las manufacturas textiles en la Prehistoria: las placas de telar en el Calcolítico peninsular. Zephyrus 49, 125-45
Champion, T.C. 1980. Settlement and environment in later Bronze Age Kent. In Barrett \& Bradley (eds) 1980, 223-46

Chevillot, C. \& Coffyn, A. (eds). 1991. L'Age du Bronze atlantique: ses facies, de l'Ecosse à l'Andalousie et leurs relations avec le bronze continentale et la mediterrannée: Actes du 1er Colloque du Parc Archéologique de Beynac. Beynac-et-Cazenac: Association des Musées du Sarladais

Cotton, J., Mills, J. \& Clegg, G. 1986. Archaeology of West Middlesex: the London Borough of Hillingdon from the earliest hunters to the late medieval period. Uxbridge: Hillingdon Borough Libraries

Crowe, K. 1982. Excavations in Essex, 1981: Barling. Essex Archaeology \& History 14, 133

Cunliffe, B. 2005. Iron Age Communities in Britain: an account of England, Scotland and Wales from the seventh century BC to the Roman conquest. 4th edn. London: Routledge

Cunliffe, B. 2009. Looking forward: maritime contacts in the first millennium вС. In P. Clark (ed.), Bronze Age Connections: cultural contact in prehistoric Europe, 80-93. Oxford: Oxbow Books

Cunliffe, B. \& Poole, C. 1991. Danebury: an Iron Age hillfort in Hampshire. Volume 4: the excavations 19791988: the site. London: Council for British Archaeology Research Report 73

Davies, A. 2006. The Charred Plant Remains from Cobham Golf Course, Cobham, Kent (ARC CGC98). York: Archaeology Data Service, CTRL Integrated Site Report Series

Drewett, P. 1982. Later Bronze Age downland economy and excavations at Black Patch, East Sussex. Proceedings of the Prehistoric Society 48, 321-400

Evans, C. \& Hodder, I. 2005. The Haddenham Project, Vol. II: Marshland communities and cultural landscape. Cambridge: McDonald Institute for Archaeological Research

Field, D. \& Needham, S. 1986. Evidence for Bronze Age settlement on Coombe Warren, Kingston Hill. Surrey Archaeological Collections 77, 127-51

Framework Archaeology. 2010. Landscape Evolution in the Middle Thames Valley: Heathrow Terminal 5 excavations Volume 2. Oxford \& Salisbury: Framework Archaeology

Gerloff, S. 2010. Atlantic Cauldrons and Buckets of the Late Bronze and Early Iron Ages in Western Europe. Prähistorische Bronzefunde II,18. Munich: Franz Steiner

Germany, M. 2003. Excavations at Great Holt's Farm, Boreham, Essex, 1992-94. Chelmsford: East Anglian Archaeology 105

Gilbert, D.R., Moore, J. \& Williams, G. (eds). 2013. 'The Landscape is Changing...': Archaeological Excavations at Nevendon Washlands, Basildon, Essex. Beckley: John Moore Heritage Services

Gollop, A. 2005. Westwood Cross, Broadstairs. Canterbury's Archaeology 2003-04, 18-9

Greatorex, C. 2005. Later prehistoric settlement in the Hoo peninsula: excavations at Kingsmead Park, Allhallows. Archaeologia Cantiana 125, 67-81 
Grimes, W.F. \& Close-Brooks, J. 1993. The excavation of Caesar's Camp, Heathrow, Harmondsworth, Middlesex, 1944. Proceedings of the Prehistoric Society 59, 303-60 Grömer, K. 2010. Prähistorische Textilkunst in Mitteleuropa: Geschichte des Handwerkes und Kleidung vor den Römern. Vienna: Naturhistorisches Museum

Groves, J. \& Lovell, J. 2002. Excavations within and close to the Late Bronze Age enclosure at the former Queen Mary's Hospital, Carshalton, 1999. London Archaeologist, 13-9

Guttman, E.B. \& Last, J. 2000. A Late Bronze Age landscape at South Hornchurch, Essex. Proceedings of the Prehistoric Society 66, 319-59

Hayman, G., Jones, P. \& Poulton, R. 2012. Settlement Sites and Sacred Offerings: prehistoric and later archaeology in the Thames valley, near Chertsey. Woking: Spoilheap Publications

Heppell, E.M. 2010. The Greater Thames Estuary Historic Environment Research Framework: update and revision of the Archaeological Research Framework for the Greater Thames Estuary (1999). Chelmsford: Essex County Council

Hoad, S., Knight, H. \& Elsden, N. 2010. Home Farm, Harmondsworth Lane, Sipson, London UB7, London Borough of Hillingdon: an archaeological post-excavation assessment and updated project design. London: Museum of London Archaeology

Howell, I. (ed.). 2005. Prehistoric Landscape to Roman Villa: excavations at Beddington, Surrey, 1981-7. London: Museum of London Archaeological Service Monograph 26

Howell, I., Swift, D., Watson, B., Cotton, J. \& Greenwood, P. 2011. Archaeological Landscapes of East London: six multi-period sites excavated in advance of gravel quarrying in the London Borough of Havering. London: Museum of London Archaeology Monograph 54

Hutchings, P. 2003. Ritual and riverside settlement: a multiperiod site at Princes Road, Dartford. Archaeologia Cantiana 123, 41-79

Johnston, J. 1983-5. Excavations at Pingewood. Berkshire Archaeological Journal 72, 17-52

Jones, M.U. 1977. Prehistoric salt equipment from a pit at Mucking, Essex. Antiquaries Journal 57, 317-9

Jones, M.U. \& Bond, D. 1980. Later Bronze Age settlement at Mucking, Essex. In Barrett \& Bradley (eds) 1980, 471-83

Jones, M.U. \& Jones, W.T. 1975. The crop-mark sites at Mucking, Essex, England. In R. Bruce-Mitford (ed.), Recent Archaeological Excavations in Europe, 133-87. London: Routledge

Kendall, M. (ed.). 2000. The Archaeology of Greater London: an assessment of archaeological evidence for human presence in the area now covered by Greater London. London: Museum of London

Kerger, P. 1999. Etude du matériel archéologique de l'atelier de sauniers à De Panne (Fl.-Occ.). Lunula: archaeologia protohistorica, 74-81

Lambrick, G. 2009. The Thames Through Time: The archaeology of the gravel terraces of the Upper and Middle Thames: the Thames Valley in late prehistory, 1500BC-AD50. Oxford: Oxford University School of Archaeology for Oxford Archaeology
Lane, T.W. \& Morris, E.L. (eds). 2001. A Millennium of Saltmaking: prehistoric and Romano-British salt production in the Fenland. Sleaford: Heritage Trust of Lincolnshire

Lavender, N. 1998. Prehistoric and Romano-British activity at the William Edwards School, Stifford Clay Road, Grays: excavations 1997. Essex Archaeology \& History 29, 19-32

Lavender, N. 1999. Bronze Age and medieval sites at Springfield, Chelmsford: excavations near the A12 Boreham Interchange, 1993. Essex Archaeology \& History 30, 1-43

Lawson, A.J. 2000. Potterne 1982-5: animal husbandry in later prehistoric Wiltshire. Salisbury: Trust for Wessex Archaeology

LeClerc, J.A., Bailey, L.H. \& Wesseling, H.L. 1918. Milling and baking tests of Einkorn, Emmer, Spelt, and Polish Wheat. Agronomy Journal 10(5), 215-7

L'Helgouach, J. \& Briard, J. (eds) 2001. Systèmes fluviaux, estuaires et implantations humaines de la Prébistoire aux grandes invasions. Paris: Comité des Travaux Historiques et Scientifiques

Longley, D. 1980. Runnymede Bridge 1976: excavations on the site of a Late Bronze Age settlement. Guildford: Surrey Archaeological Society Research Volume 6

Macpherson-Grant, N. 1992. A review of Late Bronze Age pottery from East Kent. Canterbury's Archaeology 1991-92, 55-63

Manning, A. \& Moore, C. 2003. A Late Bronze Age site at Springfield Park, Chelmsford. Essex Archaeology \& History 34, 19-35

Martin, J., Schuster, J. \& Barclay, A.J. 2012. Evidence of an Early Bronze Age field system and spelt wheat growing, together with an Anglo-Saxon sunken featured building, at Monkton Road, Minster in Thanet. Archaeologia Cantiana 132, 43-52

McOmish, D. 1996. East Chisenbury: ritual and rubbish in the British Bronze Age-Iron Age transition. Antiquity 70, 68-76

Moore, C. 2002. Late Bronze Age, Romano-British and Early/Middle Saxon features at Hoo St Werburgh. Archaeologia Cantiana 122, 259-74

Moore, J. \& Jennings, D. 1992. Reading Business Park: a Bronze Age landscape. Thames Valley Landscapes: the Kennet Valley Volume 1. Oxford: Oxford Archaeological Unit

Morris, E.L. 2007. Making magic: later prehistoric and early Roman salt production in the Lincolnshire fenland. In C. Haselgrove \& T. Moore (eds), The Later Iron Age in Britain and Beyond, 430-43. Oxford: Oxbow Books

Needham, S.P. 1991. Excavation and Salvage at Runnymede Bridge, 1978: the Late Bronze Age waterfront site. London: British Museum Press

Needham, S.P. 1992. The structure of settlement and ritual in the Late Bronze Age of south-east Britain. In C. Mordant \& A. Richard (eds), L'Habitat et l'occupation du sol à l'Age du Bronze en Europe, 49-69. Paris: Editions du Comité des Travaux historiques et scientifiques

Needham, S.P. 2007. 800 BC: the great divide. In C.C. Haselgrove \& R.E. Pope (eds), The Earlier Iron Age in Britain and the Near Continent, 39-63. Oxford: Oxbow Books

Needham, S.P. 2009. Encompassing the sea: 'maritories' and Bronze Age maritime interactions. In P. Clark (ed.), 


\section{T. Champion. FOOD, TECHNOLOGY \& CULTURE: LbA PERFORATED CLAY PLATES}

Bronze Age Connections: cultural contact in prehistoric Europe, 12-37. Oxford: Oxbow Books

Needham, S.P. \& Bowman, S. 2005. Flesh-hooks, technological complexity and the Atlantic Bronze Age feasting complex. European Journal of Archaeology 8(2), 93-136

Needham, S.P. \& Burgess, C. 1980. The later Bronze Age in the Lower Thames Valley: the metalwork evidence. In Barrett \& Bradley (eds), 1980, 437-69

Needham, S.P. \& Longley, D. 1980. Runnymede Bridge, Egham: a Late Bronze Age riverside settlement. In Barrett \& Bradley (eds) 1980, 397-436

Newton, A.A.S. 2008. A Late Bronze Age to Early Iron Age enclosure and an early Anglo-Saxon cremation cemetery at the Chalet Site, Hall Road, Heybridge, Essex. Essex Archaeology \& History 39, 57-123

O'Connell, M. 1986. Petters Sports Field, Egham: excavation of a late Bronze Agelearly Iron Age site. Guildford: Surrey Archaeological Society Research Volume 10

Perkins, D.R.J., Macpherson-Grant, N. \& Healey, E. 1994. Monkton Court Farm evaluation, 1992. Archaeologia Cantiana 114, 237-316

Philp, B.J. 2002. Archaeology in the Front line: 50 years of Kent rescue 1952-2002. Dover: Kent Archaeological Rescue Unit

Philp, B.J., Garrod, D. \& French, D. 1998. Neolithic and Iron Age Sites at Darenth, Kent. West Wickham: Kent Archaeological Rescue Unit

Powell-Cotton, P.H.G. \& Crawford, O.G.S. 1924. The Birchington hoard. Antiquaries Journal 4, 223-6

Powell, A.B. 2012. By River, Field and Factories: archaeological and cultural heritage investigation on the site of the London 2012 Olympic and Paralympic Games. Salisbury: Wessex Archaeology

Prilaux, G. 2000. La production du sel a l'Age du fer: contribution a l'établissement d'une typologie a partir des examples de l'autoroute A16. Montagnac: Monique Mergoil

Proctor, J. 2002. Late Bronze Age/Early Iron Age placed deposits from Westcroft Road, Carshalton: their meaning and interpretation. Surrey Archaeological Collections 89, 65-103

Pryor, F. 1984. Excavations at Fengate, Peterborough, England: the fourth report. Northampton: Northamptonshire Archaeological Society Monograph 2

Pryor, F. 2001. The Flag Fen Basin: archaeology and environment of a fenland landscape. Swindon: English Heritage Archaeological Report

Rahir, E. 1930. La Panne: fabrication de poteries, habitats, et sepultures de l'âge de fer. Bulletin et memoires de la Société d'Anthropologie de Bruxelles 45, 10-83

Rainbird, P. 2007. The Archaeology of Islands. Cambridge: Cambridge University Press

Riehm, K. 1962. Werkenlagen und Arbeitsgeräte urgeschichtlicher Salzsieder. Germania 40, 360-400

Robarts, N.F. 1905. Notes on a recently discovered British camp near Wallington, Surrey. Journal of the Royal Anthropological Institute 35, 387-97

Robarts, N.F. 1905-06. The British town of Wallington in the first century BC. Proceedings of the Croydon Natural History \& Scientific Society 6, 143-52
Sharples, N.M. 1991. Maiden Castle: excavations and field survey 1985-6. London: English Heritage Archaeological Report 19

Sidell, J., Cotton, J., Rayner, L. \& Wheeler, L. 2002. The Prehistory and Topography of Southwark and Lambeth. London: Museum of London Archaeological Service Monograph 14

Simmonds, A., Wenban-Smith, F.F., Bates, M.R., Powell, K., Sykes, D., Devaney, R., Stansbie, D. \& Score, D. 2011. Excavations in North-west Kent 2005-2007. Oxford: Oxford Archaeology

Stebbing, W.P.D. 1934. An early Iron Age site at Deal. Archaeologia Cantiana 46, 207-9

Stevens, C.J. \& Fuller, D.Q. 2012. Did Neolithic farming fail? The case for a Bronze Age agricultural revolution in the British Isles. Antiquity 86, 707-22

Swan, V.G. 1984. The Pottery Kilns of Roman Britain. London: H.M.S.O

Tregellas, W.H. 1868. Note on finds from Kingston. Archaeological Journal 25, 154-5

Turner, R. 1999. Excavations of an Iron Age Settlement and Roman Religious Complex at Ivy Chimneys, Witham, Essex 1978-1983. Chelmsford: East Anglian Archaeology 88

van der Noort, R. 2011. North Sea Archaeologies: a maritime biography, 10,000 $B C$ to $A D$ 1500. Oxford: Oxford University Press

van der Veen, M. 1992. Crop Husbandry Regimes: an archaeobotanical study of farming in northern England $1000 B C-A D$ 500. Sheffield: J.R. Collis Publications

Wainwright, G.J. 1979. Gussage All Saints: an Iron Age settlement in Dorset. London: Department of the Environment Archaeological Report 10

Wallis, S. \& Waughman, M. 1998. Archaeology and the Landscape in the Lower Blackwater Valley. Chelmsford: East Anglian Archaeology 82

Wheeler, R.E.M. 1943. Maiden Castle Dorset. London: Report of the Society of Antiquaries of London Research Committee 12

Whittle, A.W.R., Healy, F. \& Bayliss, A. 2011. Gathering Time: dating the early Neolithic enclosures of southern Britain and Ireland. Oxford: Oxbow Books

Wickenden, N.P. 1986. Prehistoric settlement in the Romano-British 'Small Town' at Heybridge, Essex. Essex Archaeology \& History 17, 7-68

Wieser, H. 2000. Comparative investigations of gluten proteins from different wheat species: I, Qualitative and quantitative composition of gluten protein types. European Food Research \& Technology 211, 262-8

Williams, J. \& Brown, N. 1999. An Archaeological Research Framework for the Greater Thames Estuary. Chelmsford: Kent County Council and Esssex County Council

Wymer, J.J. \& Brown, N.R. 1995. Excavations at North Shoebury: settlement and economy in south-east Essex 1500BC-AD1500. Chelmsford: East Anglian Archaeology 75

Yates, D.T. 2007. Land, Power and Prestige: Bronze Age field systems in southern England. Oxford: Oxbow 


\section{RÉSUMÉ}

Nourriture, technologie et culture en Grande-Bretagne méridionale à l'âge du bronze tardif: plaques d'argile perforées de la basse vallée de la Tamise, de Timothy Champion

On reconnait depuis longtemps que les plaques d'argile cuite perforées constituent un composant de la culture matérielle de l'âge du bronze final de l'Angleterre du sud-est, mais de récentes excavations financées par un promoteur immobilier ont produit une abondance de nouveaux témoignages. On sait maintenant que ces objets, qui démontrent un degré considérable de standardisation, sont présents dans plus de soixante-dix sites, ce qui indique une répartition marquée de bord de rivière et d'estuaire le long de la basse Tamise. Leur fonction reste incertaine mais on suggère qu'elles faisaient partie des fours pour cuire le pain, une nouvelle technologie pour la préparation de la nourriture à l'âge du bronze final. Certains des plus importants assemblages de ces plaques se trouvaient sur des sites solidement fortifiés, et on suggère aussi que la cuisson et la consommation de pain étaient particulièrement associées à de tels sites de pouvoir social. On discute de leur répartition dans l'estuaire, et présente des témoignages supplémentaires de la nature spécifiquement régionale de la consommation de nourriture vers la fin de la préhistoire.

\section{ZUSSAMENFASSUNG}

Nabrung, Technologie und Kultur in der Spätbronzezeit des südlichen Großbritanniens: Perforierte Tonteller aus dem unteren Themsetal, von Timothy Champion

Perforierte Teller aus gebranntem Ton sind seit langem als ein Element der materiellen Kultur der Spätbronzezeit im südöstlichen England bekannt, jedoch haben in der jüngsten Zeit Grabungen nach dem Verursacherprinzip eine Vielfalt neuer Funde erbracht. Diese Artefakte, die einen beträchtlichen Grad an Standardisierung zeigen, sind nun von mehr als siebzig Fundorten bekannt, die eine auffällige Verteilung mit Bezug zum Fluss und der Flussmündung entlang der Themse zeigen. Ihre Funktion ist noch immer unsicher, jedoch lässt sich annehmen, dass sie Teile von Brotbacköfen sind, was eine neue Technologie der Herstellung von Lebensmitteln in der späten Bronzezeit darstellt. Einige der größten Ensembles solcher Teller wurden in besonders geschützten Siedlungen gefunden, weshalb vorgeschlagen wird, dass das Backen und Konsumieren von Brot ausdrücklich mit derartigen Orten mit sozialer Autorität verbunden war. Die flussbezogene Verbreitung der Teller wird in diesem Beitrag diskutiert und weitere Hinweise auf die regional unterschiedliche Natur der Nahrungskonsumption in der jüngeren Vorgeschichte werden vorgestellt.

\section{RESUMEN}

Comida, tecnología y cultura en el Bronce Final del sur de Reino Unido: platos de arcilla perforados del valle bajo del Támesis, por Timothy Champion

Los platos perforados de arcilla cocida se han considerado como un componente clásico de la cultura material del final de la Edad del Bronce en el sureste de Inglaterra, y sin embargo el desarrollo de nuevas excavaciones ha producido multitud de nuevas evidencias. Estos artefactos, que reflejan un alto grado de estandarización, se conocen en más de setenta sitios y reflejan una distribución marcadamente ribereña y estuarina a lo largo del bajo Támesis. Su función aún es incierta, aunque se sugiere que formaban parte de hornos de cocción de pan, una nueva tecnología para la preparación de comida en el final de la Edad del Bronce. Algunos de los mayores conjuntos de estos platos se encuentran en sitios considerablemente fortificados, y por ello se sugiere que el horneado y consumo de pan estuvieron particularmente asociados a estos sitios de autoridad social. Se discute la distribución estuarina, y se presenta una mayor evidencia, diferenciada regionalmente, para la naturaleza del consumo de comida en la prehistoria tardía. 